UDC 624.072.2.014.2-413

\title{
PLASTIC BEARING CAPACITY OF THE STEEL ELEMENT CROSS-SECTION BY INTERNAL FORCES COMBINATION AND RESTRAINT
}

\author{
Hudz Serhii $^{\text {* }}$, Gasii Grygorii ${ }^{2}$, Hasenko Anton ${ }^{3}$, Dariienko Viktor ${ }^{4}$ \\ ${ }^{1}$ Poltava National Technical Yuri Kondratyuk University https://orcid.org/0000-0002-4764-8635 \\ ${ }^{2}$ Sumy National Agrarian University https://orcid.org/0000-0002-1492-0460 \\ ${ }^{3}$ Poltava National Technical Yuri Kondratyuk University https://orcid.org/0000-0003-1045-8077 \\ ${ }^{4}$ Central Ukrainian National Technical University https://orcid.org/0000-0001-9023-6030 \\ *Corresponding author E-mail: goods.sergiy@gmail.com
}

The article examines the features of determining the bearing capacity of the steel profile cross-section, rolled or composed from three sheets with arbitrary thickness, considering the development of plastic deformations in a complex combination of different power factors that may occur during spatial loss of stability. Based on a new approach to the perception character of internal forces, the goal is to investigate their ability to redistribute between separate linear elements, on which crosssection of the beam is broken. It is proposed to increase the savings of the material by detailing the calculation.

Keywords: bimoment, buckling, torsion, partial internal forces method, restraint.

\section{НЕСУЧА ЗДАТНІСТЬ ПОПЕРЕЧНОГО ПЕРЕРІЗУ СТАЛЕВОГО ЕЛЕМЕНТА В ПЛАСТИЧНІЙ СТАДІЇ ПРИ СПОЛУЧЕННІ ВНУТРІШНІХ ЗУСИЛЬ І РОЗКРІПЛЕННІ}

\author{
Гудзь С.А. ${ }^{1 *}$, Гасій Г.М. ${ }^{2}$, Гасенко А.В. ${ }^{3}$, Дарієнко В.В. ${ }^{4}$ \\ 1,3 Полтавський національний технічний університет імені Юрія Кондратюка \\ ${ }^{2}$ Сумський національний аграрний університет \\ ${ }^{4}$ Центральноукраїнський національний технічний університет \\ *Адреса для листування E-mail: goods.sergiy@gmail.com
}

Розглянуто особливості визначення несучої здатності поперечного перерізу сталевого профілю, прокатного чи складеного із трьох листів довільної товщини, з урахуванням розвитку пластичних деформацій при складному поєднанні різних силових факторів. На основі нового підходу до аналізу характеру сприйняття внутрішніх зусиль було поставлено за мету дослідити їх здатність перерозподілятися між окремими лінійними елементами, на які розбивається поперечний переріз балки. Запропоновано збільшити економію матеріалу шляхом деталізації розрахунку. До розрахунків, у процесі виконання яких передбачається поява і потреба врахування додаткових внутрішніх зусиль обмеженого кручення, можна віднести: 1 - звичайний та альтернативний (за теорією другого порядку) розрахунок балок на загальну стійкість; 2 - розрахунок елементів на сумісну дію поперечного згину (в одній або двох площинах) і кручення в результаті ексцентричності прикладення навантаження; 3 - розрахунок балок із викривленнями у площині найменшої жорсткості. У розрахунках за теорією другого порядку, що альтернативно враховують втрату стійкості плоскої форми згину елемента, вводиться еквівалентне початкове згинальне відхилення в площині найменшої жорсткості профілю. Тоді балка починає працювати вже як просторовий елемент, і поряд зі звичайними напруженнями згину в ній виникають додаткові напруження косого згину та кручення. Для збільшення точності розрахунків із застосуванням початкових недосконалостей і наближення їх до дійсних умов роботи конструкції внутрішні зусилля, в тому числі й від закручування, потрібно визначати за цією нелінійною теорією. Вона враховує геометричну нелінійність і являє собою по суті розрахунок за деформованою схемою, в якому рівняння рівноваги записуються для деформованого стану системи. Крім цього, необхідно врахувати жорсткість конструкцій, що дискретно чи континуально розкріплюють стиснутий пояс балки в більшості практичних випадків і зменшують деформації його зміщення.

Ключові слова: бімомент, втрата стійкості, кручення, метод часткових внутрішніх зусиль, розкріплення. 


\section{Introduction}

The calculations, in the process when the appearance and need of restrained torsion additional internal forces consideration are foreseen, may include: 1 - conventional and alternative (according to the second order theory) calculation of beams for overall stability; 2 the calculation of elements for the compatible action of the transverse bend (in one or two planes) and torsion as a result of load eccentric application; 3 - the calculation of beams with curvatures in the plane of the smallest rigidity. Equivalent initial bending deviation in the plane of the most minimal rigidity is introduced in the calculations by the second order theory, which alternatively considers the element bending flat shape stability loss. Then the beam starts to work as a spatial element, and along with the usual stresses of the bend there are additional stresses of oblique bending and torsion. In order to increase the accuracy of calculations by applying the initial imperfections and approaching them to the actual working conditions of the structure, internal forces, including from twisting, should be determined by this nonlinear theory. It considers geometric nonlinearity and represents essentially the calculation by a deformed scheme, in which the equilibrium equations are recorded for the system deformed state. In addition, it is necessary to consider the rigidity of structures that discretely or continually restrain the compressed beam flange in most practical cases and reduce the deformation of its displacement. It is proposed to determine sectorial geometric properties by rigid restraint not relative to the shear centre, but relative to the point of lateral restraint, which is located on the beam rotation axis. This point can move up or down depending on the degree of restraining, i.e. stiffness and placement of attached structures.

\section{Review of research sources and publications}

The works of representatives of the German classical technical school $[1,2,3]$ can be attributed to the main sources, where there are the position of bearing capacity calculation of the rolled and composite beams in a plastic stage in a random combination of eight internal forces (longitudinal force, two transverse forces, two bending moments, two torque moments of primary and secondary torsion, flexural-torsional bimoment) by the partial internal forces method. Theoretical foundations of the theory of thin-walled rods are laid and presented in the books of the Soviet classical science school [4, 5]. The work of I-beams under the action of bending moment and bimoment is considered in the article [6]; however, in these studies, in contrast to the second order theory, there is a significant drawback, thus they do not consider the influence the rotation angle influence the value of bending moments in two planes. Experimental research of steel I-beams by a compatible bend and torsion operation was conducted under the direction of Tusnin A.R. [7]. The approbation of the second order theory in the works [ $8-10]$ demonstrates that insufficient restrained structure in an elastic stage is very sensitive to the load and curvature change, therefore, by determining the bearing capacity consideration of braces rigidity and plastic work of steel possibly can be effective, but a greater curvature is accepted $(25-50 \%)$.

\section{Definition of unsolved aspects of the problem}

The problem of rigid restrained beams calculation for building model compliance with real work of beams at complex resistance had not been solved before. As a research task, it has been decided to analyse the method of plastic bearing capacity determination and make in it adjustments that relate to the restraining and type of rolled profile.

\section{Problem statement}

Based on the acquired experience in the analysis of the distribution of internal forces in cross-section, considering the degree of restraining, it was decided to find and describe the differences in the rod work by the combination of forces from the transverse bend in two planes and restrained torsion.

\section{Basic material and results}

To calculate the limiting bearing capacity of the steel beam (non) symmetrical cross-section (Fig. 1) in the plastic stage in an arbitrary combination of internal forces it should use a separate case of the partial internal forces method (PIFM) [3]. In the case of cross-section, which can be decomposed into three rectangular elements with arbitrary thicknesses (two flanges and one web), the method is to put the origin not in the centre of gravity of the general cross-section, but in the centre of web gravity; further definition of geometric properties of general cross-section (position of the centre of gravity, angle of rotation of main axes, sectorial coordinates in case of longitudinal force, position of shear centre or by beam restraint of the centre of rotation) relative to the centre of web gravity; moving the internal forces into the coordinate system with the beginning at this point; decomposition of common internal forces into partial for each element in relation to its centre of gravity with the use of equilibrium conditions between them; checking of certain conditions of calculation for flanges bending from bending moment in a plane of smaller rigidity and bimoment; determination and comparison of residual bearing capacity of not included in the work part of the general cross-section for the bending moment with the active bending moment in the plane of greater rigidity with consideration of longitudinal force if it is necessary and reduction of bearing capacity from possible presence in place of inspection of the internal forces, leading to the appearance of tangential stresses, namely the transverse forces and to a lesser extent torque moments, but for the beams influence of the latter can be neglected without appreciable loss of accuracy.

By the example of a light slope roof purlin, it is considered in detail each of the stages of calculation, adapting it to the restrained by profiled flooring beam of the channel cross-section, hinge supported on the ends and loaded evenly distributed load (design sketch of purlin). 

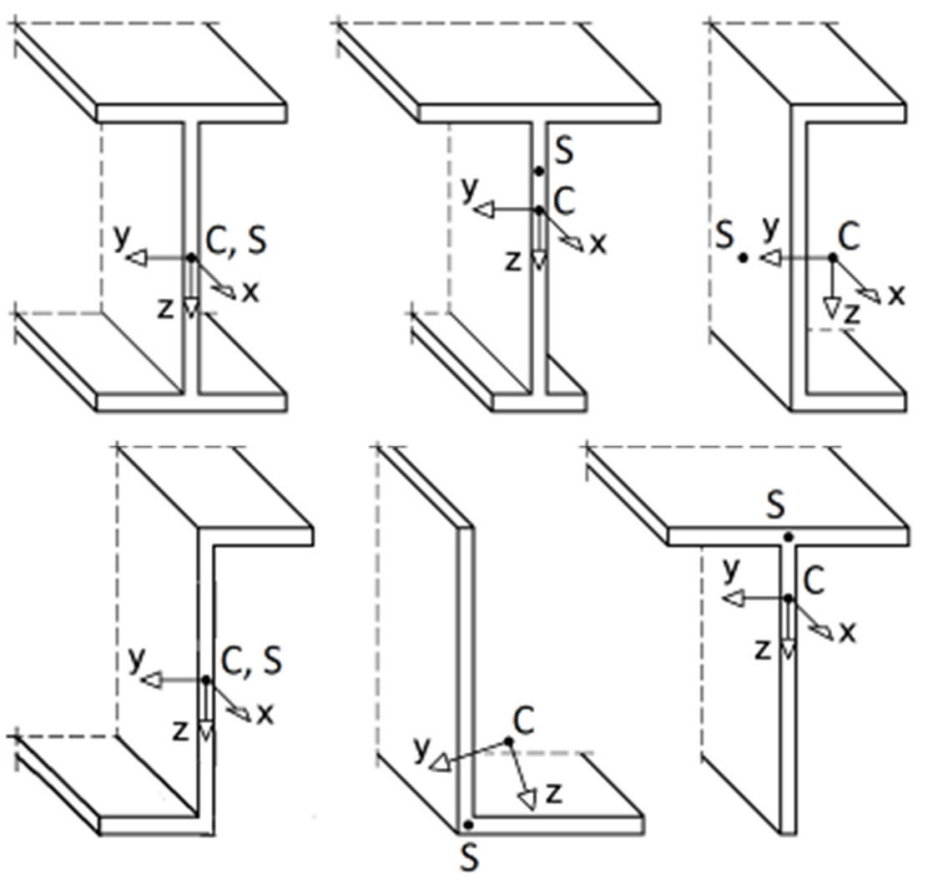

Figure 1 - Types of cross-sections that can be calculated with PIFM

It is known that with sufficient shear stiffness $S$, it is suggested that the compressed beam flange is completely fixed from the transverse displacement and rotation axis, which in this case is called restrained, passes on the beam top. Due to the high convergence of the calculation results and modelling it was discovered that for the channel with sufficient stiffness the axis of rotation is located above the shear centre at the level of the upper flange, where the slope component of load is applied that almost does not have an eccentricity in relation to that point.

Bending moments in the system with initial point in the web centre of the web in the absence of turning the main axis relative to central axis do not change ( $\left.M_{\bar{y}}=M_{y} ; M_{\bar{z}}=M_{z}\right)$. The formula for bimoment determining by the transition from the centre of rotation $D$ for restrained cross-section (the shear centre $S$ for unrestrained cross-section) to the centre of web gravity $O$ is going to look (the equation in brackets is fair for enough restrained channel cross-section - Fig. 2)

$$
\begin{gathered}
M_{\bar{\omega}}=M_{\omega}+M_{y}\left(y_{D}-y_{O}\right)+M_{z}\left(z_{D}-z_{O}\right) ; \\
\left(M_{\bar{\omega}}=M_{\omega}+M_{y} e+M_{z}\left(-0,5 h_{s}\right)\right) .
\end{gathered}
$$

Design bending moments $M_{y}, M_{z}$ regarding $y$-axis and $z$ can be determined according to the second order theory, since the consideration of lateral-torsional buckling in the partial internal forces method does not involve the use of the stability coefficient. It is necessary to consider the angle of the rod rotation and the equivalent load influence, which can be considered close due to the adoption of the bending moment diagram in the plane of smaller rigidity from the external and the stabilizing equivalent load in the form of sine wave (or parabola) with the maximum value, equal to the production of shear stiffness $S$ and beam displacement, in the middle of the span.

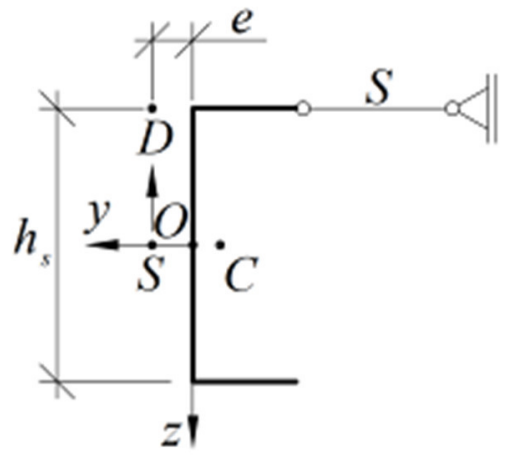

Figure 2 - Determination of the bimoment for the restrained channel beam

The actual work of the channel purlin in the inclined roofing, despite its prevalence, is often interpreted incorrectly due to the complexity of the description, which leads to analytical errors in the course of its calculation. It is especially proper for the definition of the bimoment, which depends on the function of the angle of rod rotation. The distribution of these deformations by element length is analyzed. It is important to note that in reality, the calculated bimoment depends not only on the load, its eccentricity, elastic flexural-torsional constant of cross-section and beam span, but also on the stiffness of attached to the beam structures.

Even when it is fastened the profiled flooring through the wave, its shear stiffness often reaches a sufficient value to take the restrained axis of beam rotation by the criterion of reduced necessary shear stiffness. Modelling by the finite elements analysis has shown that in this case the bending moment in the plane of the slightest rigidity decreases considerably (at the average angles of roof slope $10-30^{\circ}$ more than 10 times) and its 
influence over the total stressed-strained state is practically levelled. The angle of rod rotation function is often described in the literature via a single-member expression using half of the sine wave, which usually leads to more or less accurate results. Because the application boundaries are rarely defined clearly, negative deviations can occur. Thus the presence of profiled flooring with considerable torsional stiffness and slope component of loading can cause tangible distortion of the rotation angle distribution curve and especially its derivatives by beam length. It, in turn, causes noticeable changes in the magnitude of the bimoment.
The deformed state of the beam by torsion is better described using an expression for the angle of rotation with seven parameters, chosen for convenience of differentiation and integration, three of which are zero. A smaller number of parameters leads to too high error in bimoment determining at the beam span middle in comparison with the FEA modelling in software module FE-LTB of complex Dlubal RSTAB 8.13 (Fig. 3), although it gives the satisfactory result in the determination of deformations and equivalent stabilizing load (the possibility of applying an expression with three parameters, one of which is zero, to describe the deformation of the beam in torsion with sufficiently high accuracy proved in the work [9]).

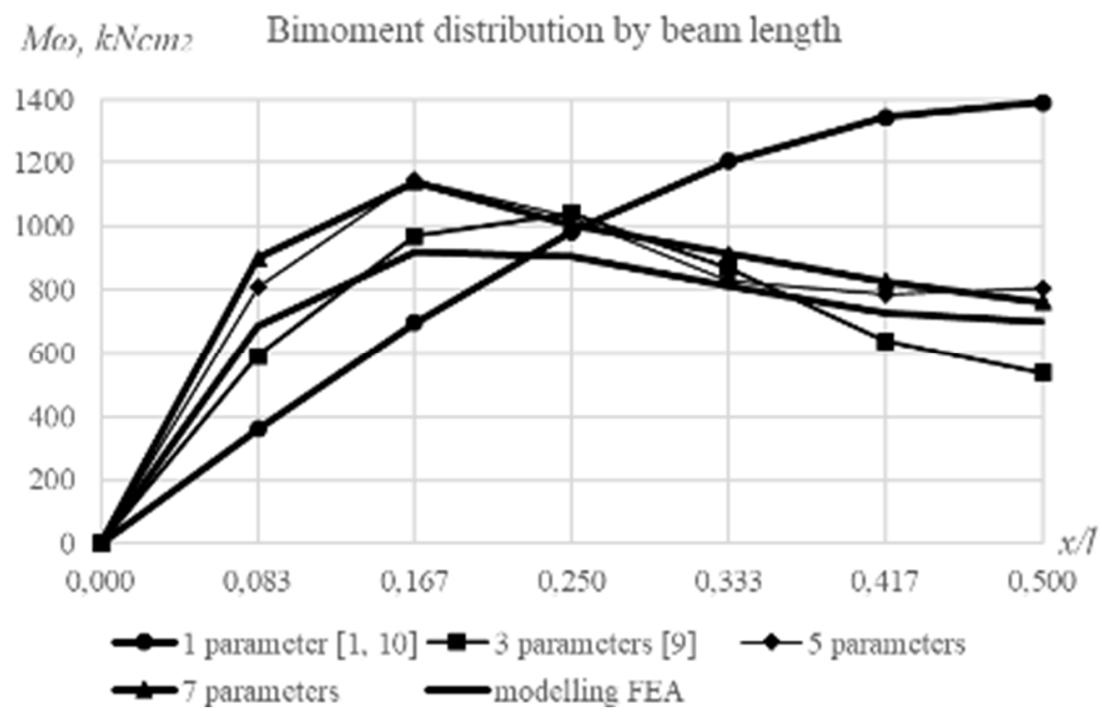

Figure 3 - Distribution of the bimoment by beam length

The partial bending moments in the bending of the upper and lower flanges with the action line at the centre of web gravity (point $O$ in Fig. 4) are equal (the equations in brackets are valid for the rolled cross-sections)

$$
\begin{gathered}
M_{\text {wao }}=\frac{M_{\bar{z}} \bar{z}_{u}-M_{\bar{\omega}}}{\bar{z}_{u}-\bar{z}_{o}} ; \\
\left(M_{\text {wao }}=\frac{M_{\bar{z}}}{2}-\frac{M_{\bar{\omega}}}{h_{s}}\right) ; \\
M_{\text {wau }}=\frac{-M_{\bar{z}} \bar{z}_{o}+M_{\bar{\omega}}}{\bar{z}_{u}-\bar{z}_{o}} ; \\
\left(M_{\text {wau }}=\frac{M_{\bar{z}}}{2}+\frac{M_{\bar{\omega}}}{h_{s}}\right) .
\end{gathered}
$$

Formulae for determination of bearing capacity for longitudinal force and bending moment for upper and lower flanges with different sizes (in brackets - with the same sizes) in a plastic stage of work by the absence in the cross-section of tangential stresses are

$$
\begin{gathered}
N_{p l o}=b_{o} t_{o} f_{y} ; N_{p l u}=b_{u} t_{u} f_{y} ; \\
\left(N_{p l o}=N_{p l u}=b_{f} t_{f} f_{y}\right) ; \\
M_{p l o}=0,25 N_{p l o} b_{o} ; M_{p l u}=0,25 N_{p l u} b_{u} ; \\
\left(M_{p l o}=0,25 N_{p l o} b_{f}=M_{p l u}=0,25 N_{p l u} b_{f}\right) .
\end{gathered}
$$

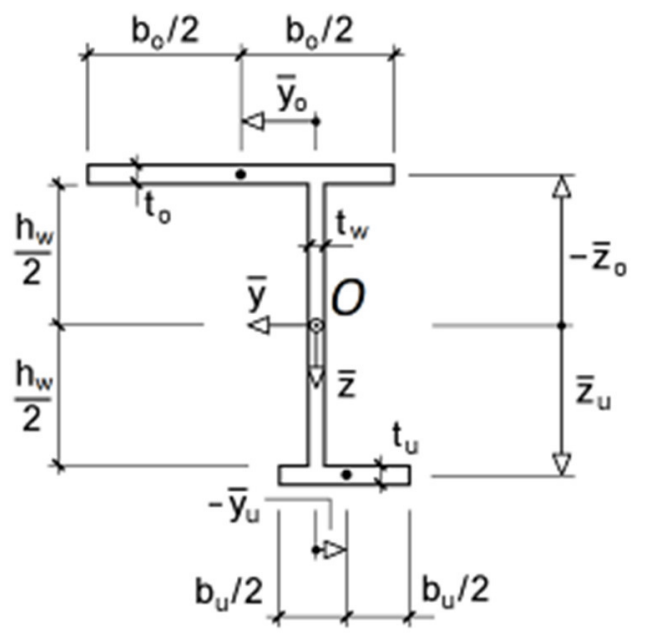

Figure 4 - Idealization of cross-section with arbitrary dimensions of elements 
The equation (2) and (3) can be converted into the partial bending moments when bending the upper and lower beam flanges with the action line at the centre of the flange gravity

$$
\begin{aligned}
& M_{o}=M_{\text {wao }}+N_{o} \bar{y}_{o} ; \\
& M_{u}=M_{\text {wau }}+N_{u} \bar{y}_{u},
\end{aligned}
$$

where $N_{o}, N_{u}$ - partial longitudinal forces in the flanges;

$\bar{y}_{o}, \bar{y}_{u}$ - coordinates of gravity centres for flanges in relation to the centre of web gravity.

These relationships are used in the equation of internal forces interaction for the rectangular cross-sections (for $i=o, u$ ):

$$
\left(\frac{N_{i}}{N_{p l i}}\right)^{2}+\frac{\left|M_{i}\right|}{M_{p l i}} \leq 1 \Rightarrow\left(\frac{N_{i}}{N_{p l i}}\right)^{2}+\left|\frac{M_{w a i}}{M_{p l i}}+2 \delta_{i} \frac{N_{i}}{N_{p l i}}\right| \leq 1,
$$

where $\delta_{i}=2 \frac{\bar{y}_{i}}{b_{i}}-$ conditional relative coefficient.

Marginal partial longitudinal forces in the flanges are found as roots as a result of equation (8) solution:

$$
\begin{gathered}
N_{f i \text { min }}=N_{p l i}\left(-\delta_{i}-\sqrt{\delta_{i}^{2}+1-\frac{M_{w a i}}{M_{p l i}}}\right) \text { for } \frac{M_{w a i}}{M_{p l i}} \geq 2 \delta_{i} ;(9) \\
N_{f i \min }=N_{p l i}\left(\delta_{i}-\sqrt{\delta_{i}^{2}+1+\frac{M_{w a i}}{M_{p l i}}}\right) \text { for } \frac{M_{w a i}}{M_{p l i}}<2 \delta_{i} ;(10) \\
N_{f i \max }=N_{p l i}\left(\delta_{i}+\sqrt{\delta_{i}^{2}+1+\frac{M_{w a i}}{M_{p l i}}}\right) \text { for }-\frac{M_{w a i}}{M_{p l i}} \geq 2 \delta_{i}
\end{gathered}
$$

$$
N_{f i \max }=N_{p l i}\left(-\delta_{i}+\sqrt{\delta_{i}^{2}+1-\frac{M_{w a i}}{M_{p l i}}}\right) \quad \text { for } \quad-\frac{M_{w a i}}{M_{p l i}}<2 \delta_{i}
$$

From the sub root expressions contained in equations (9) - (12), the conditions for calculating of sufficient bearing capacity of flanges are received:

$$
\frac{\left|M_{\text {wao }}\right|}{M_{\text {plo }}} \leq 1+\delta_{o}^{2} ; \frac{\left|M_{\text {wau }}\right|}{M_{p l u}} \leq 1+\delta_{u}^{2} .
$$

The active bending moment in the plane of greater rigidity at zero longitudinal force is compared with the minimum and maximum bearing capacity of not included in the work part of the general cross-section for the bending moment (for rolled cross-sections $\left.\bar{z}_{u}=0,5 h_{s} ; \bar{z}_{o}=-0,5 h_{s}\right)$

$$
\begin{gathered}
M_{\min } \leq M_{\bar{y}} \leq M_{\max } ; \\
M_{\text {min }}=N_{f u \min } \bar{z}_{u}+N_{f o \max } \bar{z}_{o}- \\
-\left(N_{w}^{2}-\left(N_{f o \max }+N_{f u \min }\right)^{2}\right) \frac{h_{w}}{4 N_{w}} ; \\
M_{\max }=N_{f u \max } \bar{z}_{u}+N_{f o \min } \bar{z}_{o}+ \\
+\left(N_{w}^{2}-\left(N_{f o \min }+N_{f u \max }\right)^{2}\right) \frac{h_{w}}{4 N_{w}},
\end{gathered}
$$

where $N_{w}$ - bearing capacity of a web for the longitudinal force; considering the radius rounding $R$ in place of the flange connection with the web for the channel cross-section $N_{w}=h_{w} t_{w} f_{y}+0,43 r^{2} f_{y}$; for I-rolled crosssection $N_{w}=h_{w} t_{w} f_{y}+0,86 r^{2} f_{y}$;

$h_{w}$ - height of the beam web.

Developed on the basis of partial internal forces, method technique of determination of the limiting bearing capacity of steel element cross-section with the compatible action of transverse bending and torsion for rolled and composite beams (I-beams or channels cross-section) differs from the original technique and from the principles described in the work [11]; the proposal consideration the full degree of profile restraining is by replacing the shear centre on the centre of rotation, as well as radius rounding at the flange connection with the web. The technique was implemented in the software environment MathCAD and tested on examples. Verification of the method under the same conditions of calculation (internal forces, geometric dimensions of cross-section and strength) in a file with macros QSTTSV-3Blech study program RUBSTAHL-Programme implemented by author of the partial internal forces method J. Frickel and C. Wolf showed almost identical similarity. It reflects the correct understanding and application of the partial internal forces method, which enables for the light slope roof purlins to rationally increase the coefficient of cross-section use on average by about $25 \%$ compared to the elastic work due to available strength reserves.

\section{Conclusions}

Consideration the factors specified in the article describing the peculiarities of the steel element operation at the complex resistance enables to determine the values of internal forces that affect the overall stressedstrained state of the structure and regulate calculated ratio more precisely and accurately. Determination of existing reserves of the plastic work of steel can be carried out by calculating the bearing capacity of beams in a plastic stage by the partial internal forces method in the action of bending moments and bimoment and making more the maximal initial curvature. The verification of mathematical apparatus for determination of bearing capacity of imperfect elements that are affected by bending with torsion as a result of presence of geometric nonlinearity is conducted.

\section{References}


1. Kindmann R. (2008). Stahlbau, Teil 2: Stabilität und Theorie II. Ordnung. Berlin: Ernst \& Sohn.

https://doi.org/10.1002/9783433600030

2. Kindmann R. \& Ludwig C. (2014). Plastische Tragfähigkeit von gewalzten und geschweißten I-Querschnitten. Stahlbau, 83(12), 890-904

https://doi.org/10.1002/stab.201410223

3. Kindmann R. \& Frickel J. (2017). Elastische und plastische Querschnittstragfähigkeit. Grundlagen, Methoden, Berechnungsverfahren, Beispiele. Online-Auflage.

4. Власов В.3. (1959). Тонкостенные упругие стержни. Москва: Физматгиз.

5. Бычков Д.В. (1962). Строительная механика стержневых тонкостенных конструкций. Москва: Госстройиздат.

6. Туснин А.Р., Прокич М. (2014). Работа симметричных двутавровых сечений при развитии пластических деформаций и действии изгибающего момента и бимомента. Инженерно-строительный журнал, 5(49), 44-53 https://doi.org/10.5862/MCE.49.5

7. Туснин А.Р., Прокич М. (2015). Экспериментальные исследования работы балок двутаврового сечения при действии изгиба и кручения. Инженерно-строительный журнал, 1, 24-31.

https://doi.org/10.5862/MCE.53.3

8. Hudz S.A., Gasii G.M. \& Pents V.F. (2018). The Problem of Consideration Torsion Emergence in Beams. Intern. Journal of Engineering \& Technology, 7(3.2), 141-148. http://dx.doi.org/10.14419/ijet.v7i3.2.14392

9. Kindmann R. \& Krahwinkel M. (2001). Bemessung stabilisierender Verbände und Schubfelder. Stahlbau, 70, 885-899

https://doi.org/10.1002/stab.200102860

10. Kuhlmann U. (2009). Stahlbau-Kalender 2009: Schwerpunkt - Stabilität. Berlin: Ernst \& Sohn. https://doi.org/10.1002/9783433600320

11. Beyer A., Khelil A., Boissonnade N. \& Bureau A. (2017). 13.08: Plastic resistance of $U$ sections under majoraxis bending, shear force and bi-moments, Ce/Papers, $1(2-3), 3751-3760$

https://doi.org/10.1002/cepa.431
1. Kindmann R. (2008). Stahlbau, Teil 2: Stabilität und Theorie II. Ordnung. Berlin: Ernst \& Sohn. https://doi.org/10.1002/9783433600030

2. Kindmann R. \& Ludwig C. (2014). Plastische Tragfähigkeit von gewalzten und geschweißten I-Querschnitten. Stahlbau, 83(12), 890-904

https://doi.org/10.1002/stab.201410223

3. Kindmann R. \& Frickel J. (2017). Elastische und plastische Querschnittstragfähigkeit. Grundlagen, Methoden, Berechnungsverfahren, Beispiele. Online-Auflage.

4. Vlasov V.Z. (1959). Thin-walled elastic rods. Moscow: Fizmatgiz.

5. Bychkov D.V. (1962). Structural mechanics of rod thinwalled structures. Moscow: Gosstroyizdat.

6. Tusnin A.R., Prokich M. (2014). The work of symmetric I-sections in the development of plastic deformations and the action of bending moment and bimoment. Civil Engineering Journal, 5(49), 44-53

https://doi.org/10.5862/MCE.49.5

7. Tusnin A.R., Prokich M. (2015). Experimental studies of the work of I-beams under the action of bending and torsion. Civil Engineering Journal, 1, 24-31.

https://doi.org/10.5862/MCE.53.3

8. Hudz S.A., Gasii G.M. \& Pents V.F. (2018). The Problem of Consideration Torsion Emergence in Beams. Intern. Journal of Engineering \& Technology, 7(3.2), 141-148. http://dx.doi.org/10.14419/ijet.v7i3.2.14392

9. Kindmann R. \& Krahwinkel M. (2001). Bemessung stabilisierender Verbände und Schubfelder. Stahlbau, 70, 885-899

https://doi.org/10.1002/stab.200102860

10. Kuhlmann U. (2009). Stahlbau-Kalender 2009: Schwerpunkt - Stabilität. Berlin: Ernst \& Sohn. https://doi.org/10.1002/9783433600320

11. Beyer A., Khelil A., Boissonnade N. \& Bureau A. (2017). 13.08: Plastic resistance of $U$ sections under majoraxis bending, shear force and bi-moments, Ce/Papers, $1(2-3), 3751-3760$

https://doi.org/10.1002/cepa.431 